\title{
SQUAMOUS CELL CARCINOMA IN THE FOOT: CASE SERIES AND LITERATURE REVIEW
}

\section{CARCINOMA EPIDERMOIDE NO PÉ: SÉRIE DE CASOS E REVISÃO DA LITERATURA}

\author{
Irocy Guedes Knackfuss ${ }^{1 \dagger}$, Vincenzo Giordano ${ }^{2}$, Alexandre Leme Godoy-Santos ${ }^{3}$, Nurimar Conceição Fernandes ${ }^{1}$ \\ Olavo Pires de Camargo 3
}

1. Department of Orthopedics and Traumatology, Faculdade de Medicina da Universidade Federal do Rio de Janeiro, Rio de Janeiro, RJ, Brasil (In memoriam). 2. Prof. Nova Monteiro Orthopedics and Traumatology Service, Hospital Municipal Miguel Couto, Rio de Janeiro, RJ, Brazil.

3. Department of Orthopedics and Traumatology, Hospital das Clinicas HCFMUSP, Faculdade de Medicina, Universidade de São Paulo, SP, Brazil.

\section{ABSTRACT}

Objectives: To report a case series of squamous cell carcinoma (SCC) in the foot, describing previous risk factors, surgical treatment, histopathological findings, and functional and oncological results. Methods: Nine consecutive patients diagnosed with SCC of the foot were treated at a single institution and prospectively analyzed for risk factors related to the disease, surgical outcome, and histopathological, functional and oncological results. All patients had identifiable risk factors for SCC. Results: Definitive treatment consisted of partial (6 patients) or total (3 patients) amputation of the foot. The functional score was good or excellent in the surviving patients. Early identifiable risk factors are present in most patients. Biopsy when this diagnosis is suspected, in association with oncological principles, avoids diagnostic and treatment errors. Conclusion: Despite delayed diagnosis and surgical treatment with partial and total amputations of the foot in our series, we observed good oncological outcomes that avoided systemic spread of the disease and achieved expected functional results. Level of Evidence V; Case series.

Keywords: Carcinoma, squamous cell. Foot. Amputation. Metastasis.

\section{RESUMO}

Objetivo. Relatar uma série de casos de carcinoma epidermoide no pé, descrever os fatores de risco prévios, os achados histopatológicos, o tratamento cirúrgico e os resultados funcionais e oncológicos. Métodos: Nove pacientes consecutivos com diagnóstico de CE na região do pé foram tratados em uma única instituição e analisados, prospectivamente com relação aos fatores de risco da doença, ao desfecho do tratamento cirúrgico e aos resultados histopatológicos, funcionais e oncológicos. Todos os pacientes apresentavam fatores de risco identificáveis. Resultados: O tratamento definitivo consistiu em amputação parcial (seis), amputação total (três). O escore funcional foi bom ou excelente nos pacientes sobreviventes. Fatores de risco identificáveis precocemente estão presentes na maioria dos pacientes. A biópsia na suspeita diagnóstica e o uso de princípios oncológicos evitam erros de diagnóstico e de tratamento. Conclusão: Em nossa série, apesar do diagnóstico tardio e do tratamento cirúrgico com amputações parciais e totais do pé, observamos bons resultados oncológicos que evitaram a disseminação sistêmica da doença e resultados funcionais esperados. Nível de Evidência V; Série de casos.

Descritores: Carcinoma de células escamosas. Pé. Amputação. Metástase.

Citation: Knackfuss IG, Giordano V, Godoy-Santos AL, Fernandes NC, Camargo OP. Squamous cell carcinoma in the foot: Case series and Literature review. Acta Ortop Bras. [online]. 2018;26(2):108-11. Available from URL: http://www.scielo.br/aob.

\section{INTRODUCTION}

Squamous cell carcinoma (SCC) is a rare condition in the foot. ${ }^{1,2}$ The disease was first described in 1828 by Marjolin, and its malignancy was recognized by Dupuytren. ${ }^{3,4}$ SCC originates in keratinocytes and may develop a precursor lesion or de novo lesions. ${ }^{4}$ Verrucous carcinoma, which is not strongly malignant but still locally invasive and destructive, rarely leads to metastases. ${ }^{2,4}$ When untreated, the lesions may grow to large diameters. In the plantar region, they are irregularly shaped, well-demarcated, verrucous, and are also known as epithelioma cuniculatum. ${ }^{5}$ Reports in the literature state that $13 \%$ occur in the legs, and this is the most common primary cancer of soft tissue in the foot, with an incidence slightly greater than melanoma and synovial sarcoma. ${ }^{6}$

Despite numerous publications on the subject in the literature, many orthopedic physicians demonstrate a lack of familiarity with this condition in their case reports, which invariably delays diagnosis and optimal treatment. ${ }^{2,5-13}$ Treatment is usually palliative and includes aggressive and broad resection of the tumor. ${ }^{8-10}$ Metastatic disease and recurrence of the lesion are uncommon, and are largely associated with incomplete initial excision of the tumor. ${ }^{11}$

All authors declare no potential conflict of interest related to this article.

Work conducted in the Department of Orthopedics, Faculdade de Medicina, Universidade Federal do Rio de Janeiro, Rio de Janeiro, RJ, Brazil, and in the Department of Orthopedics and Traumatology, Faculdade de Medicina FMUSP, Universidade de São Paulo, São Paulo, SP, Brazil.

Correspondence: Alexandre Leme Godoy-Santos. Departamento de Ortopedia e Traumatologia da Universidade de Sáo Paulo. Rua Dr. Ovídio Pires de Campos, 333, Cerqueira Cesar, São Paulo, SP, Brazil. 05403-010. alexandrelemegodoy@gmail.com 
The objectives of this study are to report a series of cases of SCC in the foot and to describe previous risk factors, histopathological findings, surgical treatment, and functional and oncological outcomes.

\section{MATERIALS AND METHODS}

The study included patients who were surgically treated for primary SCC of the foot over a 2-year period. The study excluded all patients with metastases related to the SCC at the time of admission, patients with SCC of the skin in other areas of the body, and patients with any other type of benign or malignant skin disease in the ankle/ foot region.

The patients sought orthopedic treatment via referral from the Department of Dermatology $(n=8)$ or spontaneous request $(n=1)$. The main complaint was the presence of chronic lesions on the foot, which did not heal, occasionally bleeding and not permitting the patients to use closed shoes. Two patients had secondary infections, with purulent drainage at the time of the first medical visit. Data were collected on patient age, sex, predisposing factors from external conditions, duration of symptoms, location and size of the lesion, tumor staging, and definitive surgical treatment. ${ }^{14,15}$ Postoperative complications were analyzed, along with functional results according to the Musculoskeletal Tumor Society Score (MSTS) ${ }^{16}$ and oncological outcomes (remission, local recurrence, metastasis, and death from the disease). The MSTS score is described in Table 1. The location of the lesion was described according to the areas defined by Kirby et al. ${ }^{17}$ (Figure 1)

All patients were subjected to routine laboratory examinations and X-rays. A computed tomography scan of the abdomen was performed in two patients with metastasis to the regional lymph nodes. Incisional biopsy was performed routinely, and after the diagnosis was confirmed, the patients were surgically treated as follows: resection of the metatarsal ray was performed in 4 patients, the hallux was amputated in 2 patients, transmetatarsal amputation was performed in 1 patients, and transtibial amputation in 2 patients. We informed the patients that data relating to these cases would be published, and they provided consent (study was approved by institutional review board under number 6070/3004).

\section{Statistical analysis}

The results were analyzed using descriptive statistics for all variables. The potential link between the duration of symptoms and lesion size was assessed using Pearson correlation analysis, with $p<0.05$. Potential differences between recurrence rates (recurrence or metastasis) and functional score based on primary definitive treatment were evaluated by Fisher's exact test, with $p<0.05$. Statistical analysis was performed using SPSS v.15.0 software (SPSS Inc., Chicago, IL).

\section{RESULTS}

Nine patients were included in the study, eight men and one woman. Mean patient age at treatment was 60 years (range: $45-86$ years).
Seven individuals were Caucasians and two were Black. In seven cases the tumor was located in the forefoot (Kirby zone 5), one case on the dorsum of the midfoot (Kirby zone 3), and one case on the midfoot plantar region (Kirby zone 4). The fourth toe was affected most often. The time interval between the first symptoms and the first visit ranged from six to 120 months, with an average of 30.7 months. The clear imbalance in this variable resulted from an extremely late diagnosis in case 9 , with 120 months of evolution. The average lesion size in its largest linear dimension was $5.2 \mathrm{~cm}$ (range: $3.0-8.0 \mathrm{~cm}$ ). There was no statistical correlation between the time until diagnosis and lesion size ( $p>5 \%)$. Among the predisposing factors, all patients had some social or professional activity related to sun exposure and six (66.7\%) smoked more than one pack of cigarettes per day. The demographic data for the patients included in the study are shown in Table 2.

One (11.0\%) patient presented osseous invasion, which was seen in simple X-rays of the affected foot. (Figure 2) In the other eight patients, the X-rays were normal. None of the two patients with metastasis to the regional lymph nodes presented tomographic alterations in the abdomen. Microscopically, the most frequent

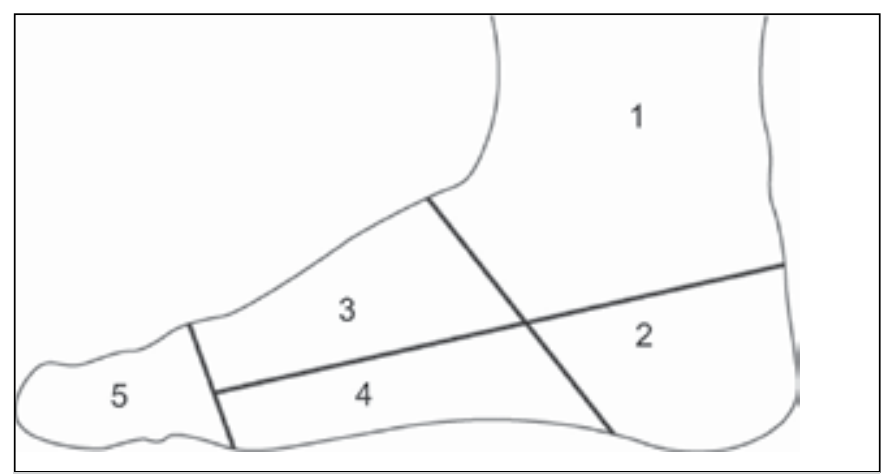

Figure 1. Zones, according to Kirby et al.

Table 2. Demographic data for the study population.

\begin{tabular}{c|c|c|c|c|c|c}
\hline Case & Age & Sex & Race & $\begin{array}{c}\text { Evolution time } \\
\text { (months) }\end{array}$ & Location & $\begin{array}{c}\text { Predisposing } \\
\text { factor(s) }\end{array}$ \\
\hline 1 & 72 & M & C & 12 & Right hallux & SE, tobacco use \\
\hline 2 & 44 & F & B & 24 & Left 2nd toe & SE \\
\hline 3 & 78 & M & C & 07 & Left 4th toe & SE \\
\hline 4 & 57 & M & C & 24 & Right hallux & SE, tobacco use \\
\hline 5 & 40 & M & C & 06 & Left foot, dorsum. & SE, tobacco use \\
\hline 6 & 86 & M & C & 24 & Left 4th and 5th toes & SE, tobacco use \\
\hline 7 & 56 & M & B & 24 & Right hallux & SE, tobacco use \\
\hline 8 & 49 & M & C & 36 & Left 4th toe & SE \\
\hline 9 & 55 & M & C & 120 & Bottom of right foot & SE, tobacco use \\
\hline
\end{tabular}

Source: DOT-UFRJ, 2017. Abbreviations: M - male, F - female, C - Caucasian, B - Black, SE - sun exposure.

\begin{tabular}{c|c|c|c|c|c|c|c}
\multicolumn{2}{l|}{ Table 1. Description of MSTS score. } \\
\hline Score & Pain & Function & Emotional & External support & $\begin{array}{c}\text { Functional } \\
\text { Independence }\end{array}$ & Gait & Percentage (\%) \\
\hline 5 & None & No restrictions & Motivated & None & Independent & Normal & 100 \\
\hline 4 & Intermediate & Intermediate & Intermediate & Intermediate & Intermediate & Intermediate & 80 \\
\hline 3 & Not disabling & Recreational limitation & Satisfied & Orthesis & Limited & Minimal alteration & 60 \\
\hline 2 & Intermediate & Intermediate & Intermediate & Intermediate & Intermediate & Intermediate & 40 \\
\hline 1 & Incapacitating & Partial limitation & Accepts & Cane/crutch & Home & Very altered & 20 \\
\hline 0 & Extremely incapacitating & Total restriction & No support & Two crutches & Dependent & Difficult & 0 \\
\hline
\end{tabular}

\footnotetext{
Source: DOT-UFRJ, 2017.
} 

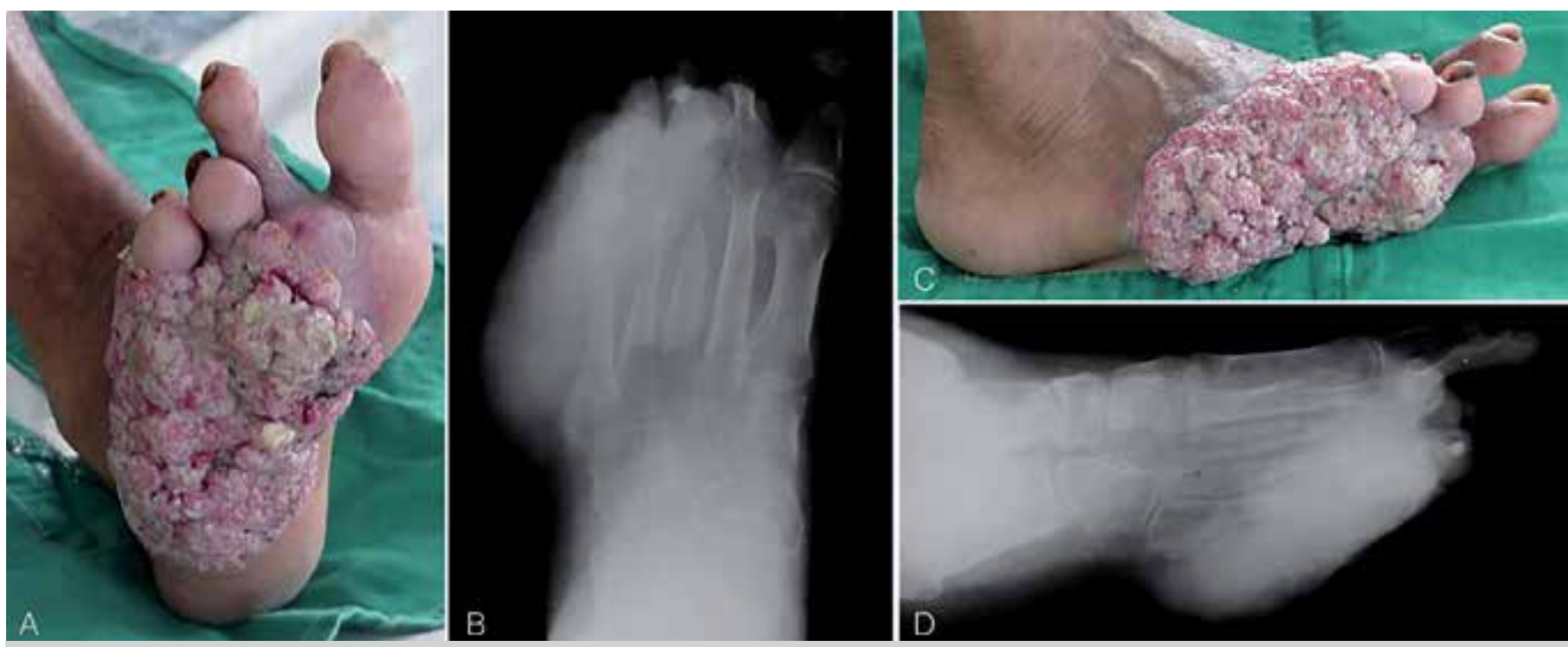

Figure 2. Case 9. Squamous cell carcinoma, ulcerative type; (A) plantar surface of the right foot, (B) anteroposterior X-ray view, (C) lateral surface of the right foot, and (D) profile X-ray view. Note the severe bone destruction caused by tumoral invasion.

histological type was well-differentiated SCC, in eight cases (88.9\%). (Figure 3) According to the TNM System for Malignant Tumor Classification from the Union for International Cancer Control (UICC), in six patients (66.6\%) the primary tumor was type T1, in two patients (22.0\%) was type T2, and one patient $(11.0 \%)$ was type T3. The complete classification is shown in Table 3.

Postoperative radiation therapy was not indicated for any patient. During the entire treatment period, the patients were monitored on an outpatient basis. The mean postoperative follow-up period was 51 months (range: 6-120 months). Two cases progressed to metastatic disease, leading to patient death (cases 1 and 9). Two cases recurred, and were treated with surgical revision and more proximal amputation (cases 3 and 6). There was no statistically significant relationship between initial definitive treatment and recurrence $(p>5 \%)$. No patient developed postoperative complications requiring additional surgical intervention, such as infection or dehiscence of the surgical scar.

The mean MSTS score was $90 \%$ (varying from $80 \%$ to $100 \%$ ), and all patients who were disease-free showed good or excellent functional results. There was no statistically significant relationship between initial definitive treatment and functional score ( $p>5 \%)$.

\section{DISCUSSION}

SCC of the foot is a rare malignant tumor of the epidermis. Although this is the most frequent malignant tumor found in the soft parts of the foot, its incidence has been described as roughly 0.6 to $3.0 \% .^{1,7,12,13}$ It is commonly associated with chronic sun exposure, due to elastic degeneration of the dermis, irregular pigmentation, and telangiectasia. ${ }^{14,18,19}$ However, SCC can also develop on ulcers, chronic granulomas, and fistular sinuses after ingestion of arsenic and exposure to tobacco smoke or radiation. ${ }^{9,12,14,20}$ In broad terms, affected patients are in their 50s and 60s, and the disease affects men more frequently than women, at a ratio of $3: 1{ }^{2,12}$ Caucasians are more likely to develop SCC. ${ }^{7,10}$ In this study, eight of the nine patients were men, the mean age at diagnosis was 60 years, and all participants reported daily exposure to ultraviolet radiation, which is common in tropical countries; three patients also smoked more than one pack of cigarettes per day.

The diagnosis is based on a high index of suspicion. Any changes in color, shape, or size, or sudden onset of pain in benign lesions of

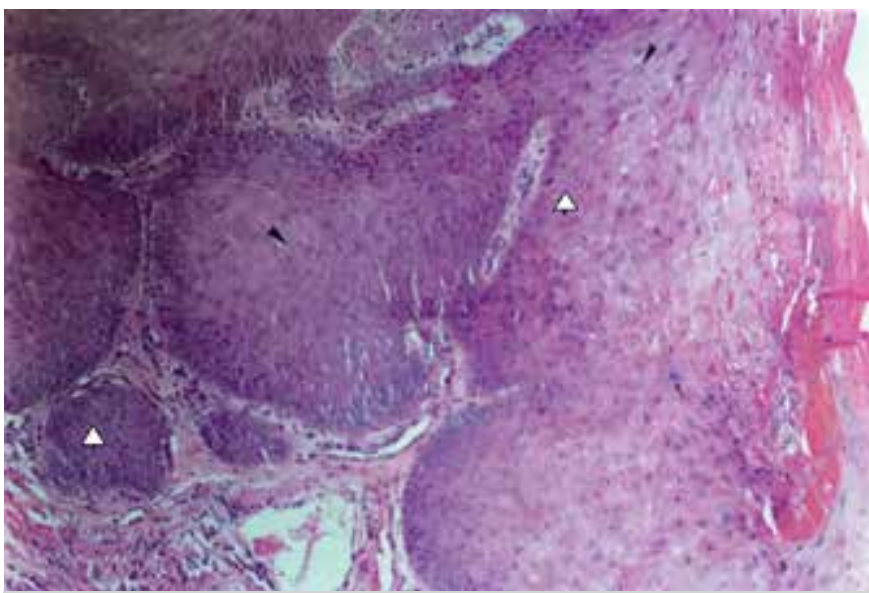

Figure 3. Case 1. Squamous cell carcinoma, ulcerative type. Photomicrograph of histological sample of the neoplasia, characterized by marked proliferation of cells in the epidermis, which appear as masses going deeper into the dermis $(\Delta)$. Note depolarization and mild cellular anomalies, characterized by occasional nuclear irregularity $(\lambda)$ and prominent nucleoli ( ). Hematoxylin and eosin, 100x.

Table 3. Morphological and histological characteristics of tumors, and TNM classification for the study population.

\begin{tabular}{c|c|c|c|c|c}
\hline Case & $\begin{array}{c}\text { Morphological } \\
\text { type }\end{array}$ & $\begin{array}{c}\text { Histological } \\
\text { type }\end{array}$ & $\begin{array}{c}\text { Primary } \\
\text { Tumor }\end{array}$ & $\begin{array}{c}\text { Regional } \\
\text { lymph nodes }\end{array}$ & Metastasis \\
\hline 1 & U & PD & T2 & N1 & M0 \\
\hline 2 & V & WD & T1 & N0 & M0 \\
\hline 3 & V & WD & T1 & N0 & M0 \\
\hline 4 & U & WD & T1 & N0 & M0 \\
\hline 5 & V & WD & T2 & N0 & M0 \\
\hline 6 & U & WD & T1 & N0 & M0 \\
\hline 7 & V & WD & T1 & N0 & M0 \\
\hline 8 & V & WD & T1 & N0 & M0 \\
\hline 9 & U & WD & T3 & N1 & M0 \\
\hline
\end{tabular}

Source: DOT-UFRJ, 2017. Abbreviations: U - ulcerative, $V$ - verrucous, WD - well differentiated PD - poorly differentiated. 
the foot should raise concerns about possible malignancy. ${ }^{11}$ Furthermore, particular attention is recommended for any chronic lesion that has difficulty healing. Incisional biopsy should be performed first for definitive confirmation of the diagnosis: ${ }^{10}$ scrape biopsy is not considered appropriate. ${ }^{2}$ Microscopically, there is disruption of the basal membrane and dermis invasion by well-differentiated keratinocyte-like cells. Corneal pearls may be present. An increase in the number of atypical cells, greater degree of anaplasia, and increased number of mitotic figures indicate little differentiation of the tumor. ${ }^{2,12}$ In some cases, the basal membrane remains intact and the carcinoma develops in situ. ${ }^{2,6}$

Treatment is based on surgical resection of the tumor. In general, lesions with regular margins should be treated with local excision. 2,6,8-10,18 Safety margins of at least 3.0-5.0 mm should be maintained, in accordance with the dermatological literature. ${ }^{6}$ In more aggressive lesions, it is difficult to establish safety margins, and consequently more proximal amputation of the foot is indicated. ${ }^{9,10}$ Complete excision of the tumor rarely leads to recurrence. In our study, two patients experienced recurrence, probably due to inadequate resection of the primary lesion, and required a higher level of amputation (cases 3 and 6). In untreated cases, SCC of the foot spreads to the regional lymph nodes.

The prognosis is determined by the presence of metastasis, lymph node involvement, treatment, and local recurrences. There is generally greater potential for metastatic disease when SCC develops on chronic ulcers, known as Marjolin ulcers. SCC is spread hematogenically as well as through the lymphatic vessels, depending on its location and its degree of aggressiveness. ${ }^{7,12}$ In general, metastasis to the lymph vessels without bone or tendon involvement is extremely rare. But when ganglionic metastasis does occur, approximately $31 \%$ of patients die within five years. ${ }^{9,19,20}$ In the present study, two patients developed metastatic disease, and died from related causes.

Prophylactic radiation of the inguinal lymph nodes and intraarterial infusion of the affected limb with methotrexate and floxuridine have been suggested after excision of the primary tumor. ${ }^{9}$ However, prophylactic lymph node resection is controversial. Glass et al. recommend palpating the inguinal lymph node chain for 36 months after tumor excision. ${ }^{20}$ Lymph node biopsy should always be performed after this period if enlarged or painful lymph nodes persist. ${ }^{9}$

\section{CONCLUSIONS}

Epidermoid carcinoma in the foot region is generally diagnosed late and subject to non-optimal initial treatment, requiring radical procedures with compromised functional results. Risk factors that can be identified early are present in the majority of patients. Biopsy in suspected cases and the use of oncologic principles can avoid errors in diagnosis and treatment. In our series, despite late diagnosis and surgical treatment with partial and total amputation of the foot, good oncological results were seen, which avoided systemic spread of the disease and provided the desired functional outcomes.

AUTHORS' CONTRIBUTIONS: Each author made significant individual contributions to this manuscript. IGK (in memoriam) * selected patients and acquired data. VG (0000-0002-4429-312X)*: acquired data, designed the study, interpreted the results, and drafted the article. ALGS (0000-0002-66721869)*: acquired data, designed the study, interpreted the results, and drafted the article. NCF (0000-0001-6037-0685)*: conducted the histological analysis, and interpreted and reviewed the data. OPC (0000-0002-1128-7292)*: evaluated the oncological basis critically reviewed the article. All authors contributed to the intellectual concept of the study and approved the final version of the manuscript. *ORCID (Open Researcher and Contributor ID).

\section{REFERENCES}

1. Price ML, Tidman MJ, Ogg CS, MacDonald DM. Skin cancer and cyclosporine therapy. N Engl J Med. 1985;313(22):1420.

2. Smith J, Mello LF, Nogueira Neto NC, Meohas W, Pinto LW, Campos VA, et al. Malignancy in chronic ulcers and scars of the leg (Marjolin's ulcer): a study of 21 patients. Skeletal Radiol. 2001;30(6):331-7.

3. Marjolin NJ. Ulcère. Dictionnaire de medecine. 1828;(21):31.

4. Da Costa JC 3rd. Carcinomatous Changes in an Area of Chronic Ulceration, or Marjolin's Ulcer. Ann Surg. 1903;37(4):496-502.

5. Potter BK, Pitcher JD Jr, Adams SC, Temple HT. Squamous cell carcinoma of the foot. Foot Ankle Int. 2009;30(6):517-23.

6. Kallini JR, Hamed N, Khachemoune A. Squamous cell carcinoma of the skin:epidemiology, classification, management, and novel trends. Int J Dermatol. 2015;54(2):130-40.

7. Guadara J, Sergi A, Labruna V, Welch M, Gazivoda PL. Transformation of plantar verruca into squamous cell carcinoma. J Foot Surg. 1992;31(6):611-4.

8. Kolker AR, Wolfort FG, Upton J, Tahan SR, Hein KD, Zewert TE. Plantar verrucous carcinoma following transmetatarsal amputation and renal transplantation. Ann Plast Surg. 1998;40(5):515-9.

9. Leis SB, Bayne O, Karlin JM, Scurran BL, Reiner M. Squamous cell carcinoma: an unusual early complication of postoperative osteomyelitis. J Foot Ankle Surg.1994;33(1):21-7.

10. Lewis J, Mendicino RW. Squamous cell carcinoma of the great toe. J Foot Ankle Surg. 1994;33(5):482-5.
11. Smith PJ Jr, Hylinski JH, Axe S. Verrucous carcinoma: epithelioma cuniculatum plantare. J Foot Surg. 1992;31(4):324-8.

12. Grady JF, Garoufalis MG, Moore CJ, Nasadowski R. Squamous cell carcinoma: a pedal case presentation. J Foot Surg. 1990;29(4):375-8.

13. Demuth RJ, Snider BL. Primary squamous cell carcinoma of the plantar surface of the foot. Ann Plast Surg. 1980;4(4):310-4.

14. Asgari MM, Efird JT, Warton EM, Friedman GD. Potential risk factors for cutaneous squamous cell carcinoma include oral contraceptives: results of a nested case-control study. Int J Environ Res Public Health. 2010;7(2):427-42.

15. Sobin LH, Gosporadowicz MK, Wittekind Ch. TNM classification of malignant tumours. Blackwell Publishing Ltd., UK. 2009; $7^{\text {th }}$ Ed.

16. Enneking WF, Dunham W, Gebhardt MC, Malawar M, Pritchard DJ. A system for the functional evaluation of reconstructive procedures after surgical treatment of tumors of the musculoskeletal system. Clin Orthop Relat Res. 1993;(286):241-6.

17. Kirby EJ, Shereff MJ, Lewis MM. Soft-tissue tumors and tumor-like lesions of the foot. An analysis of eighty-three cases. J Bone Joint Surg Am. 1989;71(4):621-6.

18. Malhotra KP, Shukla S, Husain N, Bhatt ML. Combined Squamomelanocytic Tumor of the Plantar Surface of the Foot: Histogenetic Insights. Am J Dermatopathol. 2016;38(5):396-7.

19. Soares D, Kimula Y. Squamous cell carcinoma of the foot arising in chronic ulcers in leprosy patients. Lepr Rev. 1996;67(4):325-9.

20. Wanke NCF, Avè BRC, Maceira J. Carcinoma epidermóide em úlcera angiodérmica. Relato de nove casos. An Bras Dermatol. 1990;(65):59-62. 